intact, Dr. Herz is led to the conclusion that this disease can appear with various grades of severity, and that his own cases were not of the severest form.

A careful examination of the parents failed to show any possibility of an hereditary taint as the cause of the disease. The confinement in each case was an easy one, and the absence of asphyxia in the second case does not support Hewitt's theory of an intra-uterine cause. Dr. Herz considers the diphtheritic affection of the mouth which complicated in a striking manner both his cases to stand in a causal relation to the other disturbances, and agrees with Dr. Bigelow that these changes were of a septic character.

\title{
THE MASSACHUSETTS MEDICO-LEGAL SOCIETY.
}

\section{REPORT OF THE CORRESPONDING SECRETARY, JUNE 11, 1878.}

BY MEDICAL EXAMINER FREDERIC WINSOR, M. D.

Ir must be understood that the report which $I$ have the honor to make has for its material the work of the six months ending December 31, 1877, and also that this was done under a statute of the commonwealth and under society by-laws altogether new to the medical examiners, who did the work and reported to the corresponding secretary. As a matter of course there has been, in performing duties so unfamiliar, less method, andaccuracy, promptness than may fairly be expected in the work of succeeding years.

During the six months which this report covers, forty-one of the fifty medical examiners who have joined this society made 443 "views," in 116 of which autopsies were made. Ninety-nine inquests have been held, leading to 21 prosecutions, of which 5 resulted in conviction. In these 443 cases, death resulted from natural causes in 102; from railroad accidents in 77; from other accidents in 129; from suicide in 71 ; from violence in 51.

It is of course desirable to pursue the analysis farther, and learn what modes of suicide were used, what was the most frequent form of fatal accident, etc.; but it is not possible to do so with regard to all the cases, 186 having never been reported in detail to the corresponding secretary.

Some information of interest may be obtained, however, by analyzing the remaining cases, and it appears that of 32 cases of suicide 12 were by hanging; 1 was by strangling; 6 by poison; 3 by drowning; 3 by shooting; 3 by railroad train; 2 by cutting the throat; 1 by stabbing; 1 by leaping from a height. Arsenious acid was the poison used in 2 cases, opium and morphia in 2 other cases.

Of the persons committing suicide 5 were known to be insane.

Of 64 deaths from accidents not caused by railroad carriages there were from drowning 36 ; from falls 7 ; from heavy falling articles 6 ; from inhaling coal-gas 5 ; by being run over 4 ; from machinery 2 ; from burning and scalding 2 ; from burning at lime-kiln, after suffocation by its gas, 1 ; by shooting 1 .

Of the deaths by accidental drowning, 4 were of persons previously known to be insane. 
One naturally asks, What proportion of these deaths by suicide or accident were preventable? The answer is, Very few under the existing state of things. But by judicious legislation the proportion of such deaths might be materially diminished. It is preposterous that no restrictions should be put upon the sale of poisons in this commonwealth. As the law now stands, any one can obtain for a few cents, at the nearest apothecary's shop, a fatal dose, and he may take his choice of half a dozen poisons. There is no reason to suppose that the provision of the present law, which requires the vender to keep a register of the name and residence of the persons purchasing certain specified poisons, is complied with in one quarter of the cases.

In view of the great loss of life by drowning, it seems within the function of the State to furnish instruction in swimming, and in resuscitating persons nearly drowned. To the writer it appears that such instruction might with propriety be grafted upon our public-school system. It must, however, be said that a very large proportion of the persons drowned, and so coming under the "view" of the medical examiner, were intoxicated at the time of the accident.

Much may be done to diminish the frequency of poisoning by coal-gas if the. public can be informed as to the nature of the danger and the means of prevention, and if a public sentiment can be roused against "dampers" which close smoke-pipes and obstruct the escape of poisonous gases into the open air.

It is not generally known that of fatal railroad accidents quite one half happen to persons walking on or near the track, often while intoxicated. Now, if railroad corporations and the towns through which the roads pass can devise means to prevent such walking, fifty lives would be annually saved to the commonwealth.

Finally, whatever tends to lessen drunkenness acts directly to diminish accilents of all kinds. If it were possible to put a stop to it, accidents would be diminished by one half.

Instead of criticising unsatisfactory reports of cases, and pointing out their defects, it seems wiser to submit to the society a few of the many reports which are excellent, in the hope that they may serve as standards for future work.

Case VII.' (1.) View in Wakefield, on east shore of Lake Quanaponitt.

(2.) May 22, 1878. Twelve, noon.

(3.) Summoned by H. Haskell, Jr.

(4.) Male. Age unknown, one to five days. Nationality unknown.

(5.) Name and residence unknown.

(6.) This body of a male infant was found floating in the water, a short distance from the eastern shore. Wind blowing freshly from the west. Body

1 The numeral references in these illustrative cases correspond with the following "order of items" by which members of the society are guided in preparing their reports for the corresponding secretary: (1.) State locality of view. (2.) Date and hour. (3.) By whom summoned. (4.) Sex, age, and nationality of person found dead. (5.) Name and residence of deceased (if known). (6.) Position and condition of body. (7.) Circumstances determining decision of medical examiner. (8.) Autopsy and its results. (9.) Microscopical and chemical examination. (10.) Inquest and its results; whether or not followed by prosecution and conviction of any person implicated. 
beating up and down against the rocks. On the shore near the body was a woven cotton and wool undershirt, sleeves cut off, partly filled with coarse sand. Flakes of epidermis were adherent to the inside of the shirt. The body of the infant had around its neck a piece of cord (clothes-line) $1.5 \mathrm{~m}$. in length. This cord was twice around the neck, but very loosely, and was knotted. There was also thrice around the neck a piece of cotton twine, one m. in length. The large cord was caught in a small bush at a short distance from the shore, and parted in the attempt to land it.

Time of Death. - In my opinion death occurred between May 1 and May 15, 1878.

(7.) Decision of medical examiner and circumstances determining it:-

(a.) Maturity of child. Full term. (b.) Was it born alive? Position of diaphragm, appearance and condition of lungs (hydrostatic test), contents of large intestine, would all indicate that it had lived and breathed. (c.) If born alive, how long did it live? Between twenty-four hours and five days. Absence of meconium and color of fæcal matter in colon indicated an age of more than twenty-four hours. Condition of funis, less than five days. (d.) What was the cause of its death? I see no reason to doubt that it was thrown into the water alive, and perished from drowning, being doubtless tied up in the shirt already mentioned.

(8.) Autopsy, occupying forty-five minutes. External examination. - The body is (a) that of an apparently mature infant, fifty-two cm. in length, weight about five kilogr. A well-nourished infant. Arms and legs fat. (b.) Body pale and white generally. Abdomen and scalp bluish-green. (c.) Some thin, sanguineous fluid escaped from the mouth and ears. (d.) Hair thin and scanty. Eyes flabby and colorless (opaque). No teeth. Jaw-bone protruding through mucous membrane on left side (sup. max.). Roof of mouth deficient (from decomposition). (e.) A considerable portion of the flesh of the right shoulder (half-way down the arm) appeared to be torn or gnawed away; also two small spots about the back. ( $f$.) Chest full. Abdomen much distended. (g.) Scrotum swollen. (h.) Epidermis wanting in exposed parts of the body. Adherent in the folds. (i.) Funis six $\mathrm{cm}$. in length, firm, no ligature around it.

Internal Examination. - (j.) Cranial cavity. Scalp of moderate thickness, loose and flabby. Cranial bones appear loose within it. Bones well developed for a child at maturity. Sutures widely separated. Cerebral matter entirely gone.

Thorax. (k.) Incision from neck to pubes. Adipose tissue abundant. Muscles pale. Peritoneal cavity distended with gas. (l.) Diaphragm not highly arched. (m.) Position of abdominal organs normal. Sternum removed. (n.) Right lung distended, bright red in color. Left lung less distended, reddish-purple. Both lungs crepitant, and studded on the outside with vesicles. No fluid in pleura or pericardium. The vesicles on the surface of the lungs were carefully opened, and the lungs placed in a pail of fresh water. They floated high on its surface. (o.) The heart appeared normal, about the size of the child's fist. It contained no blood in either ventricle.

Abdomen. (p.) Stomach, kidneys, and portions of small intestines decomposed, and not readily distinguishable. (q.) Liver, dark purple, soft, and read- 
ily torn. (r.) Bladder empty. (s.) Colon filled with light-brown fæcal matter. No meconium.

(9.) Microscopic examination of skin on the shirt showed it to contain hairs, and consist of similar epidermis to that upon the body of the infant.

(10.) No inquest, no additional evidence being found.

S. W. Aввотт, Medical Examiner, Third Middlesex District.

VII. (1.) View of body at Westville Street, Dorchester.

(2.) July 22, 1877 . One P. M.

(3.) Friends of the deceased.

(4.) Female. Twenty-nine. American.

(5.) Cynthia S. Phillips. Westville Street, Dorchester.

(7.) Deceased was one of a party at a picnic at Silver Lake, June 28th. She, with others, was on a small steamer whose boiler exploded, by which accident she was severely burned and scalded about the nates and posterior aspect of both thighs. She lingered in great distress twenty-five days, and died of exhaustion consequent upon her injuries. The ulcerations did not heal except at small points.

(8.) Autopsy discovered the extensive granulating ulceration above described, but nothing farther to account for death. The internal organs were healthy.

(10.) Inquest before Judge Churchill found evidence of culpable negligence on the part of the boat owners. Upon this finding was based a settlement of claims preferred by the husband of above deceased, and by other persons injured at the explosion.

The inquest in this case was ordered by the district attorney in accordance with Section 10 of Chapter 200, 1877.

F. W. Draper, Medical Examiner.

XVIII. (1.) Boston City Hospital.

(2.) August 10, 1877. 7.40 Р. м.

(3.) Hospital clerk.

(4.) Male. Sixty. Irish.

(5.) Dennis O'Brien. 143 Ruggles Street, Boston.

(6 and 7.) In the course of an altercation with one James Hurl, the deceased, who was drunk, was thrown to the ground, and in that position was punched by Hurl with his knees. O'Brien at once gave loud groans, as if in great pain, and was unable to walk. He was carried to the hospital, where he died on the day following, showing symptoms of internal hæmorrhage.

(8.) An autopsy found two quarts of red fluid exudation in the abdomen and thorax together; two ribs were broken; two ribs on one side and four on the other were loosened and partly detached from their spinal articulation; the lower lobe of the right lung was engorged; the liver was lacerated superficially on its inferior surface; in the interior were two clots of blood of the size of a lemon.

(10.) An inquest by Judge Churchill found Hurl guilty of manslaughter, but the grand jury reported "no bill."

F. W. Draper, Medical Examiner. 
XLIII. (1.) 45 Melrose Street, Boston.

(2.) October $27,1877.7 .20$ P. M.

(3.) Police.

(4.) Male. New-born. Unknown (if not "American").

(5.) James Williams. 45 Melrose Street, Boston.

(6 and 7.) This new-born baby was found dead by its mother's side in bed. The mother had concealed her pregnancy and her labor, and the condition of things was discovered by people in the house by accident. The child had been born three hours when found ; the mother said it lived " a few minutes." She had no baby clothes ready, and had made no engagements of doctor, or nurse, or lying-in help. She claimed that her husband was dead.

(8.) Autopsy. No marks of violence. A portion of cord eleven inches long hung from navel; its end was ragged, as if torn off. Lungs were crepitant and buoyant, showing respiration. Foramen ovale of heart was closed. The meninges were congested.

(10.) Inquest found infanticide by neglect, and the case came before the grand jury. "No bill." F. W. Draper, Medical Examiner.

(1.) City of Taunton. County of Bristol. In house on Court Street, where deceased had lived.

(2.) November 1, 1877. Three A. M.

(3.) The police.

(4.) Male. Sixty-five years. Irish.

(5.) Patrick Laughna. Taunton. Court Street.

(6.) Lying upon floor of kitchen, without mark or bruise.

(7.) The fire-alarm was struck, and Laughna got up, as had been his custom in such cases, and opened the window to look for the fire. Soon his daughter heard the sash fall, and heard her father groan. She came to him, and found him hanging by the neck, the sash resting upon the back and side of his neck. She released him, but " he breathed but once or twice afterwards."

(8.) No autopsy.

(10.) No inquest.

Silas D. Presbrex, Medical Examiner.

\section{CLARKE ON VISIONS. ${ }^{1}$}

THE parts of this book which will awaken the deepest interest are at the beginning and the end. This is not to detract from the force of the reasoning, the ingenuity of speculation, or the clearness of the language with which Dr. Clarke sets forth his views in the body of the work; but the book as a whole is most valuable in some of its suggestions and almost involuntary admissions.

We find no very new physiological truths set forth, but rather the teachings of modern physiology applied with Dr. Clarke's well-known precision of thought and distinctness of language to a subject just so far in the border land of physiology that many are inclined, in discussing it, either to relax a

1 Visions : A Study of False Sight (Pseudopia). By Edward H. Clarke, M. D. With an Introduction and Memorial Sketch by Oliver Wendell Holmes, M. D. 